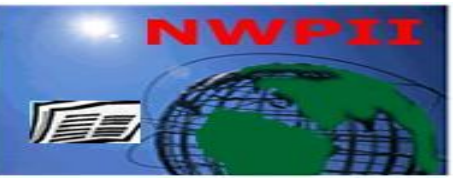

American Journal of Biomedical Sciences

ISSN: 1937-9080

nwpii.com/ajbms

\title{
Clinical Analysis of Patients with Small Cell Prostate Carcinoma
}

\author{
TongLi Hao, YiGuang Wu*, BaoFa Hong, Lai Zhang, WenZheng Chen, Gang Li
}

Urology Department, Chinese PLA General Hospital, 1000853, China

*Corresponding author

YiGuang Wu, MD

Doctor in charge

Ward 3, Urology Department, Chinese PLA General Hospital

FuXing Load No28

HaiDian Strict, Beijing (1000853)

P.R. China.

Tel: +86-10-66875510

E-mail: wuyiguang876@ sina.com

\begin{tabular}{l|l|l} 
Received: 4 May 2010; & Revised: 16 July 2010; & Accepted: 13 August 2010
\end{tabular}

\begin{abstract}
The aim of this work was to investigate the prognostic value of the small cell prostate carcinoma. The data of patients with prostate carcinoma were retrospectively analyzed in this study, including the immunohistochemical methods, PSA level, Gleason score and the patients survival time. The tumor specimens were stained by neuron specific enolase(NSE), synaptophysin (SYN), chromogranin A (CgA) and NED (Neuroendocrine differentiation). Small cell carcinoma of prostate was detected in 5 cases by biopsy or autopsy. Metabasis was found in 4 patients when the small cell prostate carcinoma was diagnosed. One patient died post-diagnosis of 1 month, one patient died in 6 months, while the other 3 patients died in 3 years. The 5 year survival rate of patients with the small cell prostate carcinoma was significantly lower than that of the other prostate carcinoma patients. The expression of NED has positive correlation to Gleason score. NED was related to the prostate carcinoma patients' surviva1. The results indicated that the combination detection of NED markers and Gleason score could provide useful information of prognosis for the patients with small cell prostate carcinoma. The progression to small cell prostate carcinoma indicated a poor prognosis and slight changes in the serum prostate-specific antigen level. Early diagnosis and early treatment might improve the prognosis of the patients diagnosed as small cell prostate carcinoma.
\end{abstract}

Keywords: small cell prostate carcinoma; neuroendocrine differentiation; prognosis.

\section{Introduction}

The biology characteristic and pathologic process of prostate cancer was very complicated, some special types of prostate cancer (such as neuroendocrine type) developed very quickly, resulting in death in the short term. The high degree of neuroendocrine cancer was called small cell carcinoma, it showed validity to androgen 
blockage at the beginning, but appeared resistant to hormone therapy very quickly.

Small cell carcinoma (SCC) was a very rare tumor, comprising $0.5 \% \sim 2 \%$ of all prostatic carcinomas [1]. Oesterling et al. [2] reported that $67 \%$ of all SCC of the prostate are pure SCC from the beginning. Some reports showed SCC was in an advanced stage from conventional adenocarcinoma; post hormone therapy [3-5].

This paper summarized the integrity clinical data of 5 patients diagnosed as SCC of prostate, including specific immunity histochemistry index, the PSA level, Gleason grade score and the time of hormone therapy resistance as observed index. We analyzed the relation between the NED (Neuroendocrine Differentiation) of prostate cancer and survival time to reveal the characteristics of clinical diagnosis and treatment of small cell prostate carcinoma.

\section{Materials and methods}

From March 2005 to August 2009, we confirmed 5 patients of small cell prostate carcinoma. Patients ranged in age from 65 to 92 years (mean: 73.5y), all 5 patients were confirmed by gland puncture with the assistance of transrectal ultrasound.

One individual, a male patient, 79 years old, was admitted because of the increase of PSA level for 2 years on November $19^{\text {th }}, 2008$. The level of total PSA was $26.45 \mathrm{ng} / \mathrm{ml}$, but the level of total PSA was 5ng/ml in April 2006, while on October 20th, 2008, the level of total PSA was increased to $18.25 \mathrm{ng} / \mathrm{ml}$ and reexamining at the same time, the level of Free-PSA was $1.68 \mathrm{ng} / \mathrm{ml}$. Fever was found during 20 days before hospitalization. The laboratory check showed liver, kidney function abnormality, acid-base imbalance, and electrolyte disturbances. His whole body stained yellow, there was a sign of ascites (+), the body temperature was 38 39 degrees, the prostate gland quality was hard, very obvious in the left side leaf. CT check on November $20^{\text {th }}, 2008$ hinted the prostate gland appearance mess, seminal vesicles encroachment, lymphoid knot of pelvic cavity and posterior abdominal cavity being extensively swollen. In addition there were signs of metastatic liver lesion, midrange abdominal dropsy and pleural effusion.

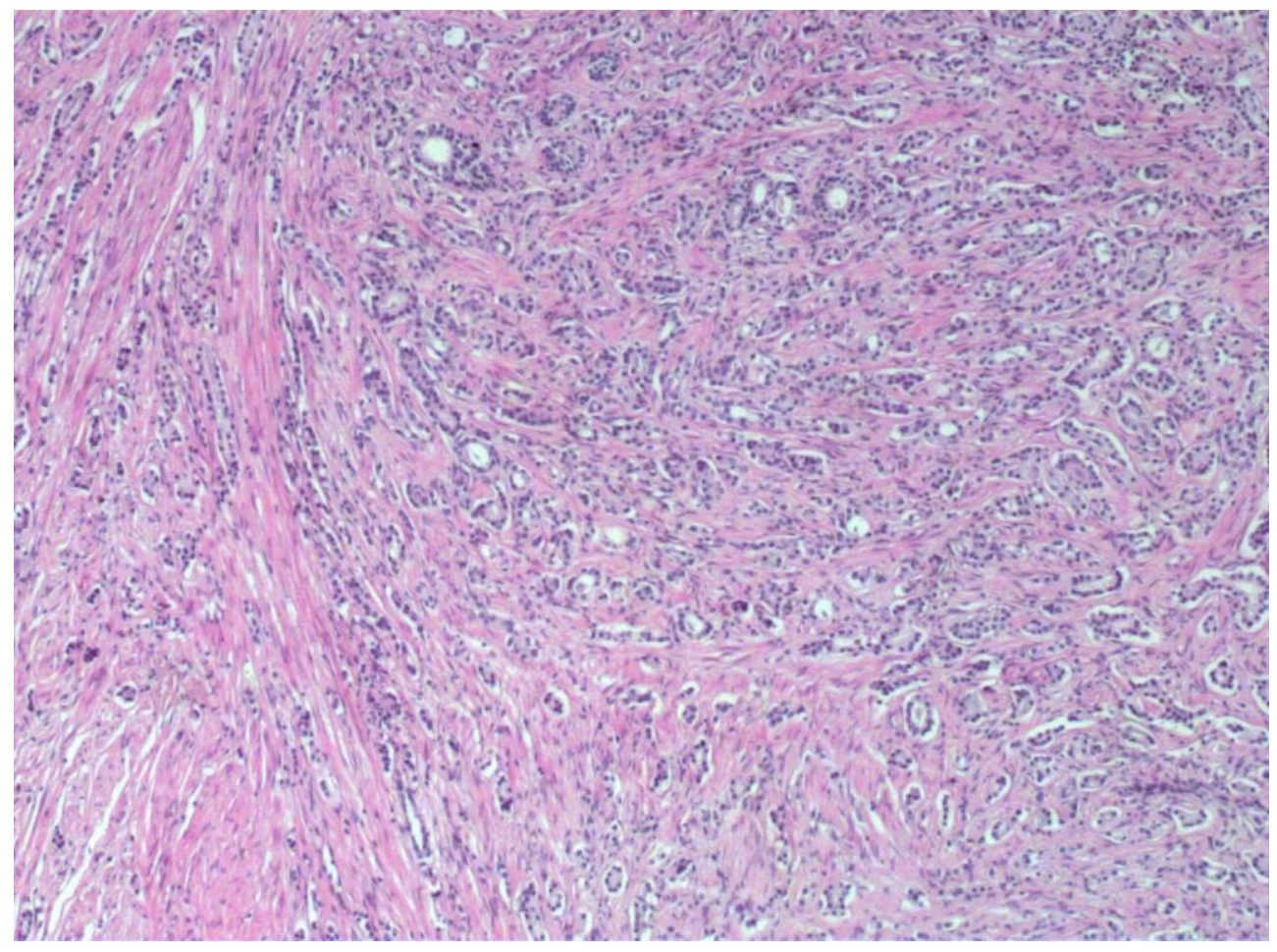

Figure 1 The pathological section of prostate adenocancer (HE staining, $\times 100)$ 


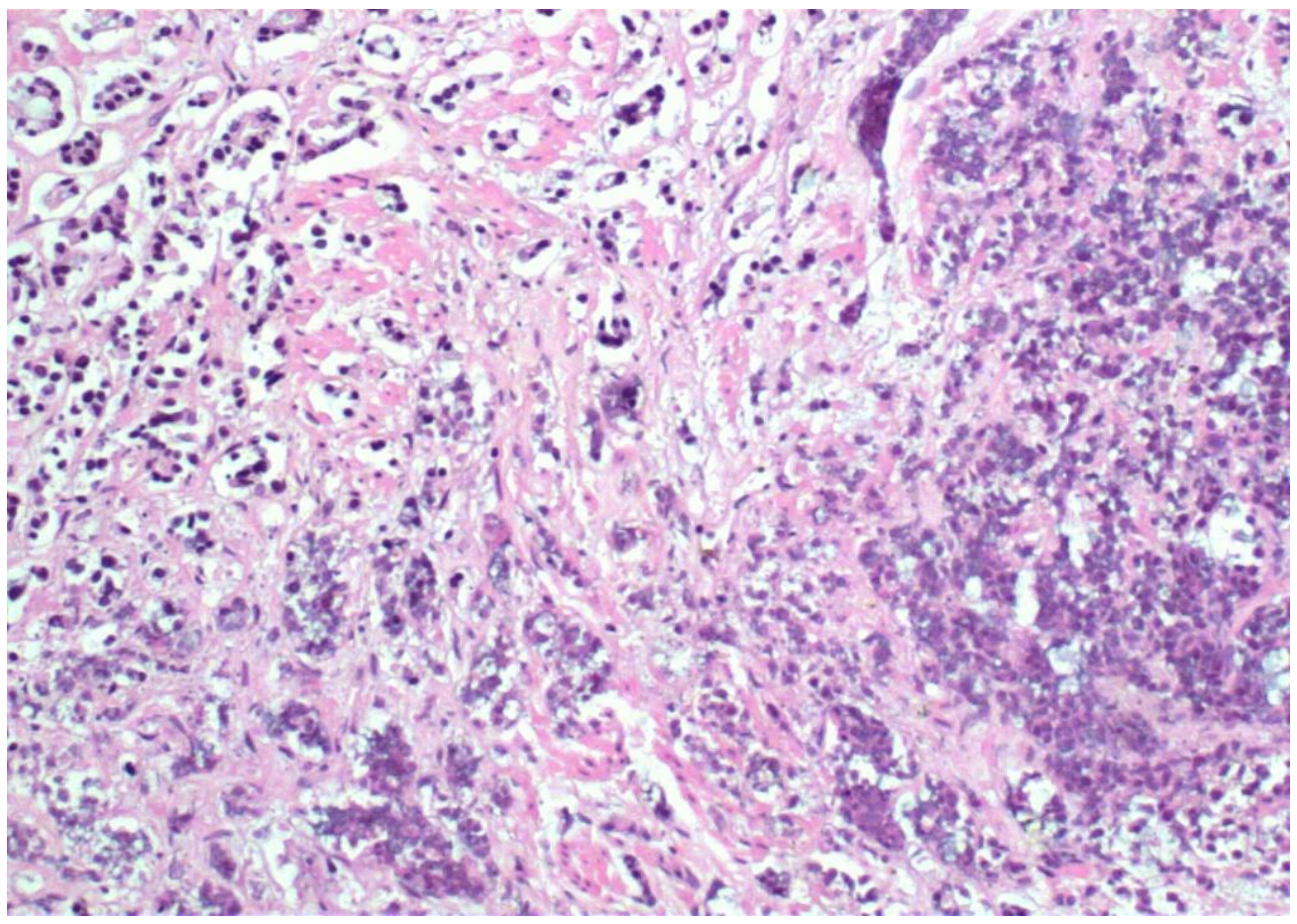

Figure 2 The pathological section of juncture between prostate adenocancer and small cell cancer (HE staining, $\times 200$ )

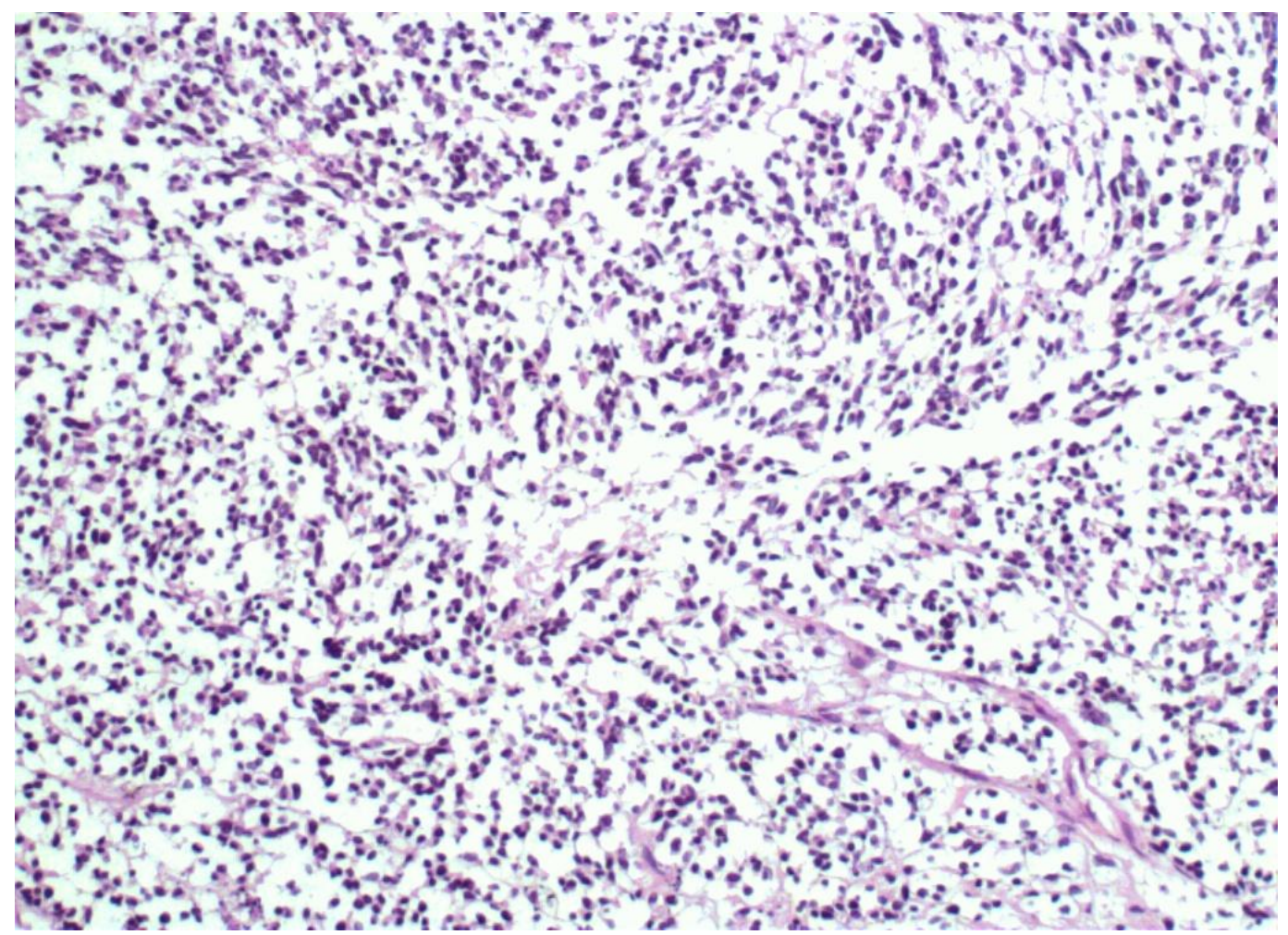

Figure 3 The pathological section of prostate small cell cancer (HE staining, $\times 100$ ) 


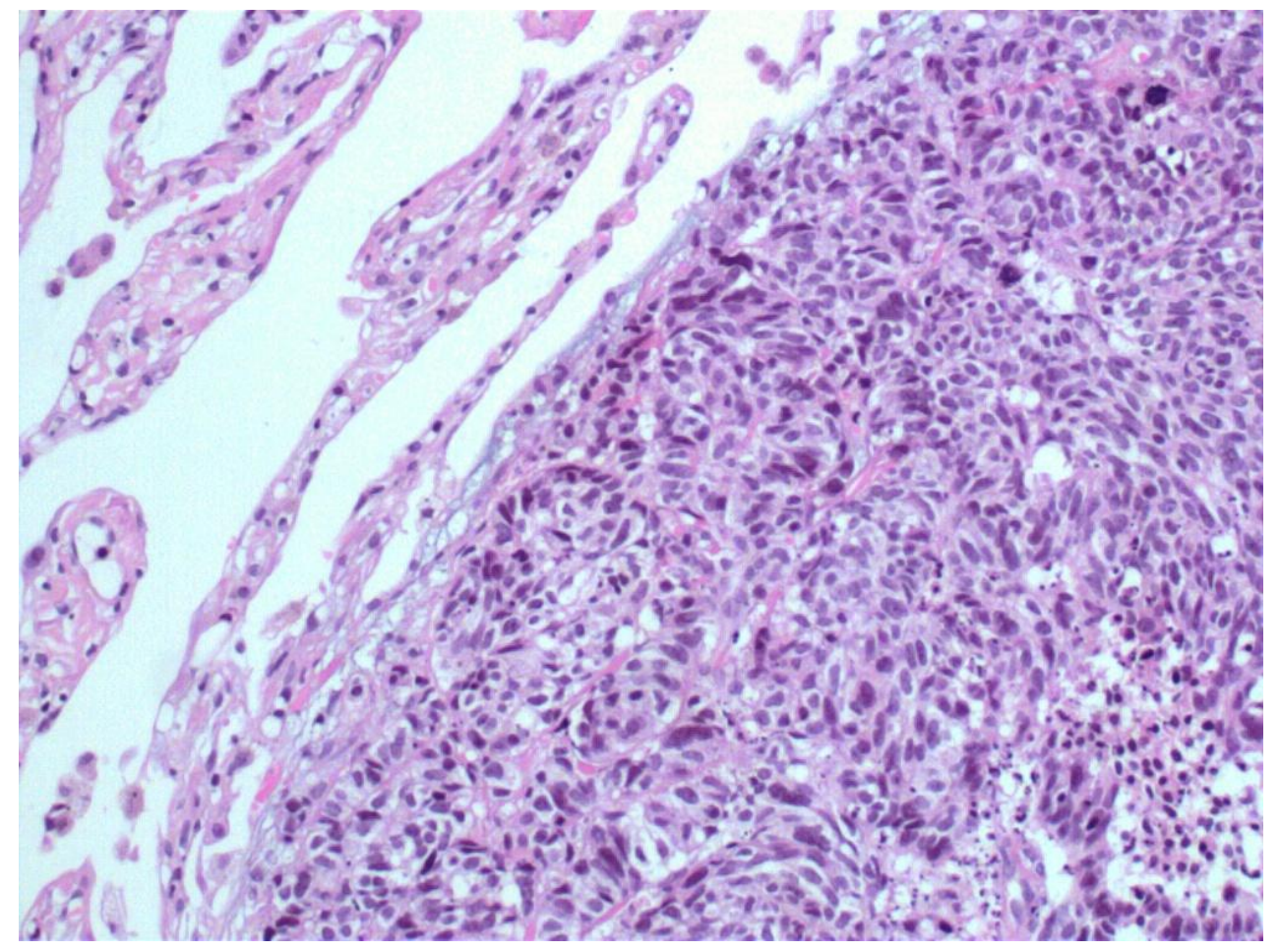

Figure 4 The pathological section of pulmonary metastasis small cell cancer (HE staining, $\times 200$ )

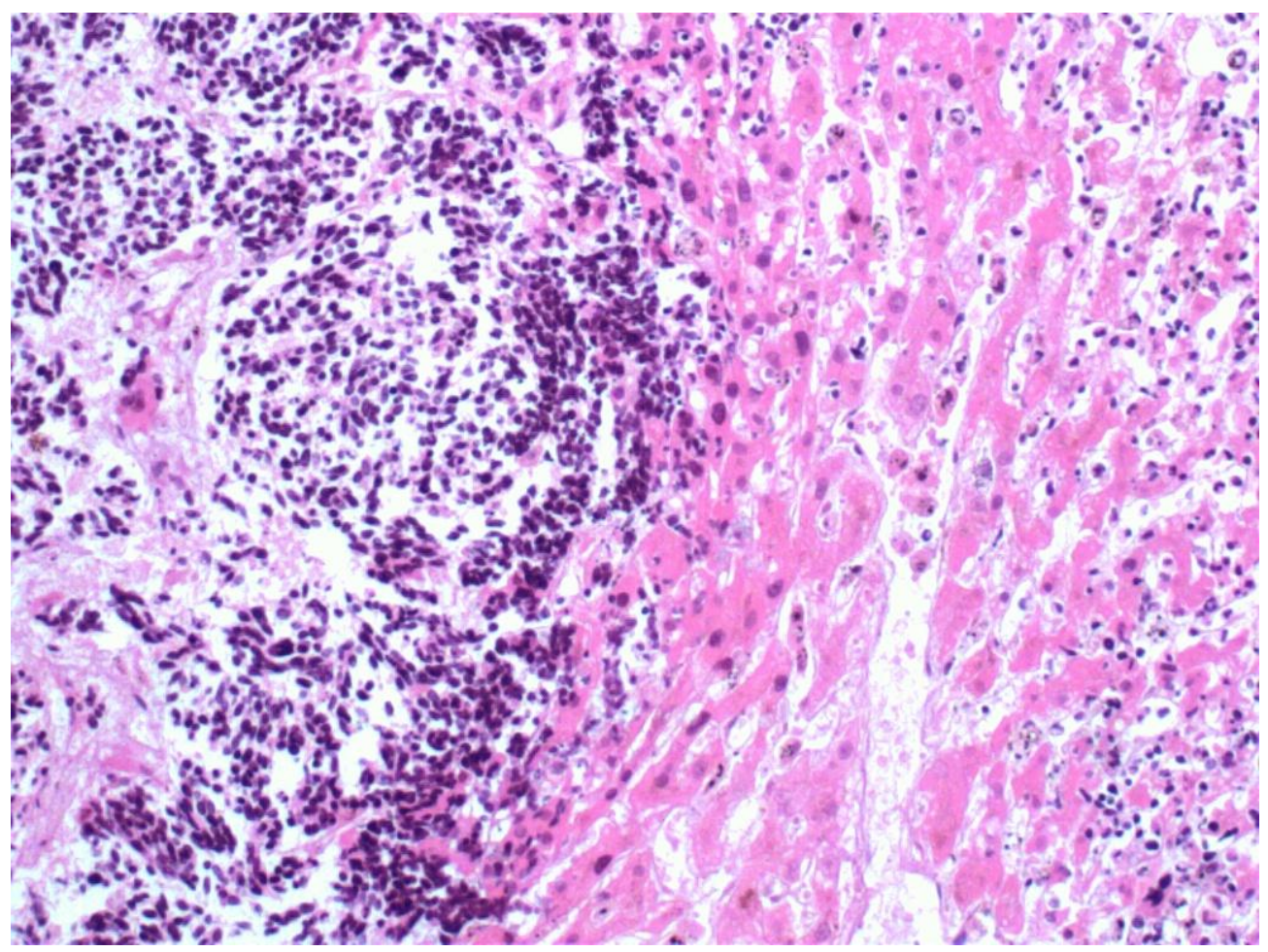

Figure 5 The pathological section of hepatic metastasis small cell cancer (HE staining, $\times 200$ ) 


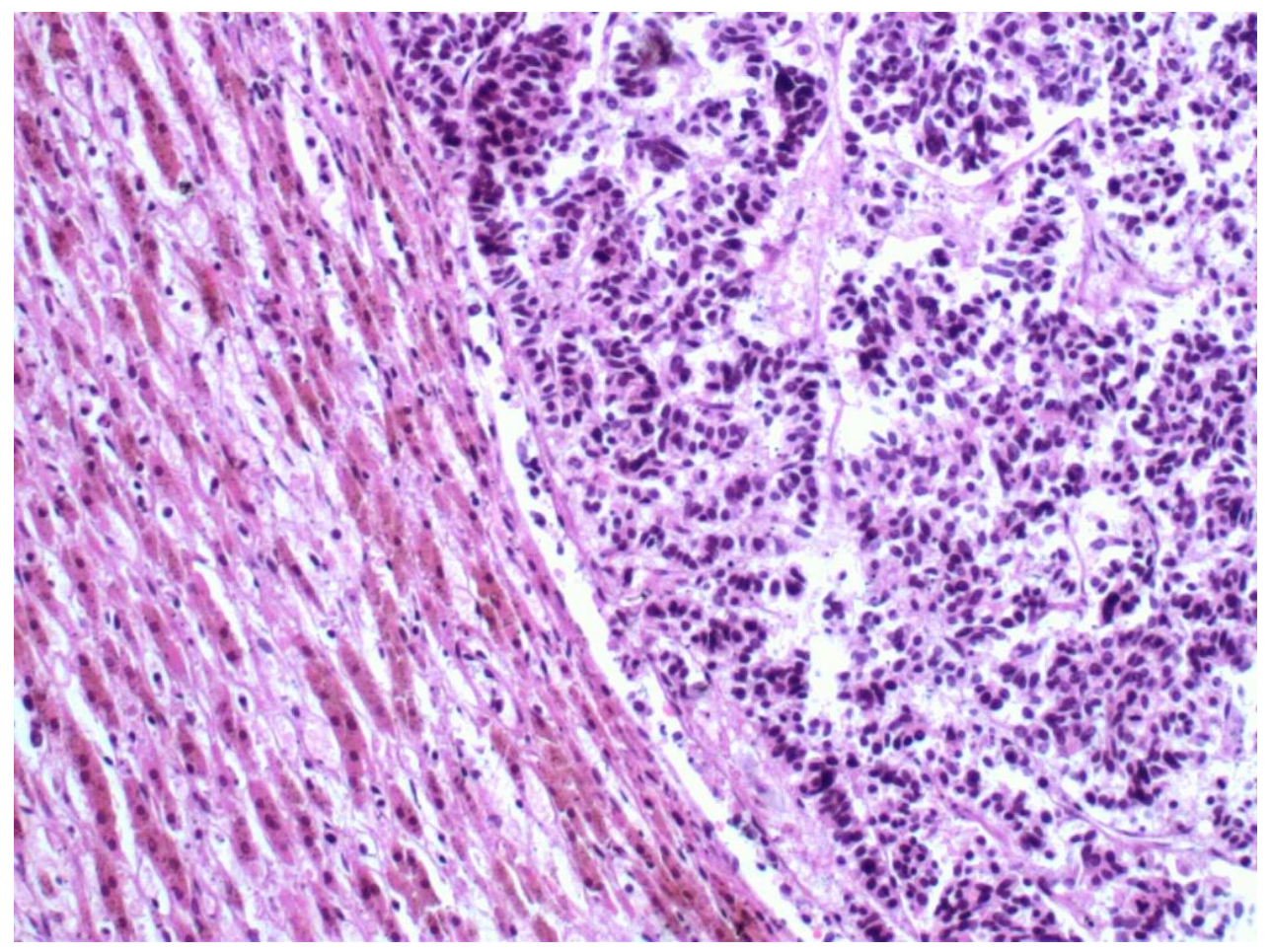

Figure 6 The pathological section of adrenal metastasis small cell cancer (HE staining, $\times 200$ )

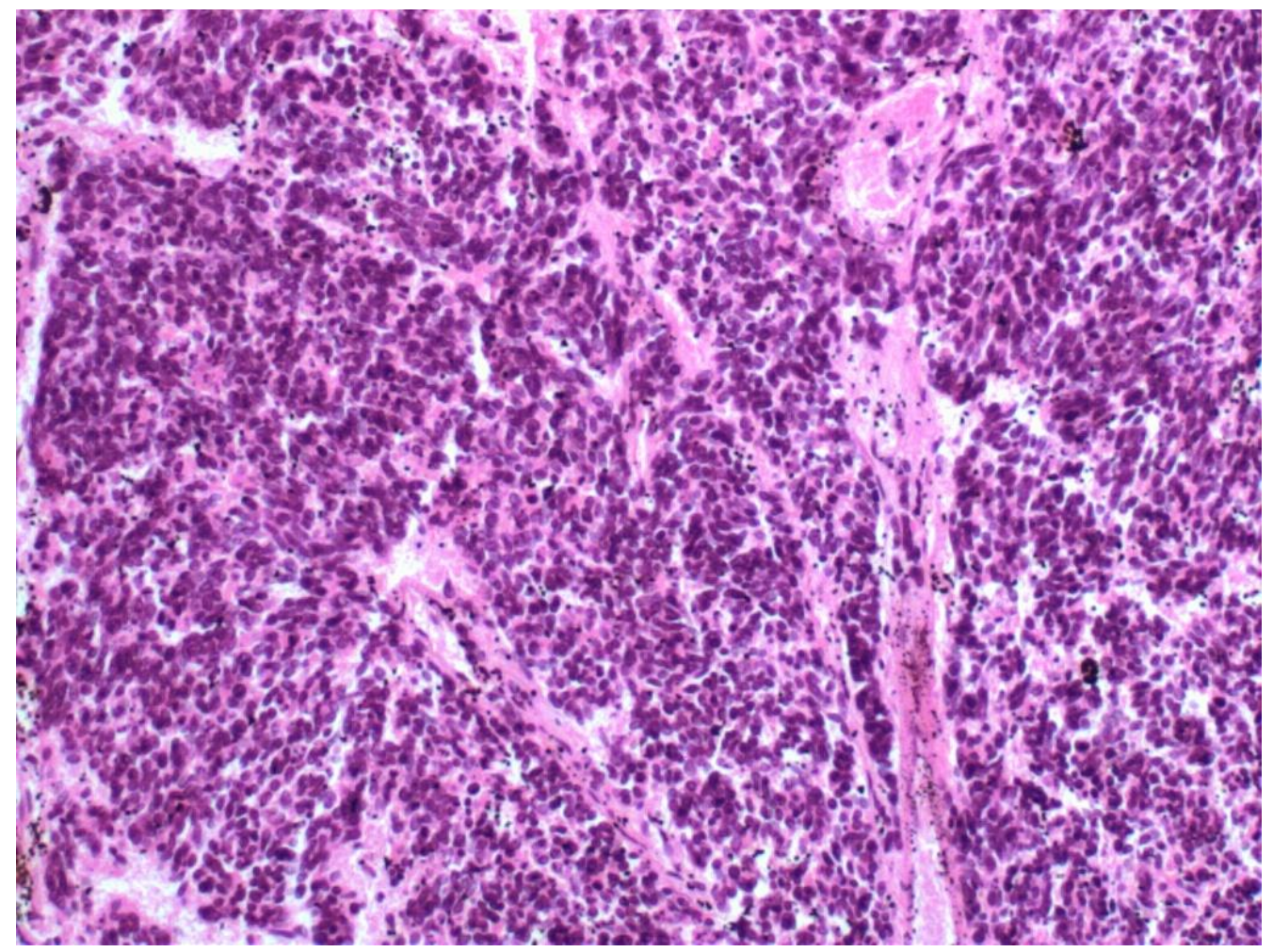

Figure 7 The pathological section of pancreatic metastasis small cell cancer $(\mathrm{HE}$ staining, $\times 200)$ 
The whole body bone scanning showed many spots of osseous metastasis. On December $4^{\text {th }}$, 2008, he was given the prostate puncture at the bed side by ultrasound leading. On December $5^{\text {th }}$, 2008, his condition sharply worsened, and he died of circulatory and respiratory failure on December 8th, 2008. The autopsy post-operation resulted in the prostate gland cellule having poorly differentiated cancer and many organs' metabasis, such as abdominal cavity, liver, kidney, lung, bone, post peritoneum, etc. Pathologic description: Gleason grade score: $5+4=9$. Cell heteromorphism was obvious, it was clear of big but irregular nucleoli. immunohistochemistry: PSA (+), neuron specific enolase(NSE) (+++), synaptophysin (SYN ) (+) and chromogranin $\mathrm{A}(\mathrm{CgA})(++)$. The pathological sections were shown in figure 1 7.

\section{Table 1: The clinical data in the small cell carcinoma of the prostate}

\begin{tabular}{|c|c|c|c|c|c|c|c|}
\hline Age $(Y e$ & $\begin{array}{l}\text { ar) Gleas on } \\
\text { Score } \\
(A+B)\end{array}$ & $\begin{array}{l}\text { Total PSA Level at } \\
\text { Final Diagnosis } \\
\text { (ng/mL) }\end{array}$ & $\begin{array}{l}\text { Metabasis } \\
(\mathrm{Y} / \mathrm{N})\end{array}$ & Androgen Resistance Time and Prognosis & $\begin{array}{l}\text { CGA } \\
(+ \text { or }-)\end{array}$ & $\begin{array}{r}\text { NSE } \\
(+ \text { or }-)\end{array}$ & $\begin{array}{l}\text { SYN } \\
(+ \text { or }-)\end{array}$ \\
\hline 66 & $4+4=8$ & 4.10 & $\mathrm{Y}$ & 6 Months, Small Cell Prostate Carcinoma & $H$ & $H$ & + \\
\hline 67 & $4+4=8$ & 652 & $\mathrm{Y}$ & 18 Months, Small Cell Prostate Carcinoma & - & ++ & + \\
\hline 73 & $4+3=7$ & 13.56 & $\mathrm{Y}$ & 12 Months, Small Cell Prostate Carcinoma & $H$ & + & + \\
\hline 79 & $5+4=9$ & 18.25 & $\mathrm{Y}$ & 1 month, Small Cell Prostate Carcinoma & $H$ & + & + \\
\hline 72 & $4+4=8$ & 17.69 & $\mathrm{Y}$ & 3 month, Small Cell Prostate Carcinoma & $H$ & +4 & + \\
\hline
\end{tabular}

\section{Discussion}

The normal prostate gland is constituted of base cell, exocrine cell and nerve endocrine cell (Neuroendocrine cell, NE cell). The NE cell was ordinarily seen in transitional zones and came from the endepidermis stem cell; it didn't carry on caryocinesia. The heteromorphism of NE cell in the prostate cancer was obvious, the big and irregular nucleole was clear. The NE cell can secrete various neurosecretions, including chromogranin $\mathrm{A}, \mathrm{B}(\mathrm{CgA}, \mathrm{CgB})$, NSE, parathyroid hormone-related peptide, calcitionin and gastrin. The NE cell can be identified through the immunohisto- chemistry method by positive stain of a marker, such as CgA, Syn and NSE [6-8].

The rate of nerve endocrine cell in patients of prostate cancer was $10 \%$ to $32.5 \%$. If the neuroendocrine cell counted above $50 \%$, and had the particular structure of neuroendocrine tumor, then it could be diagnosed as a prostate neuroendocrine cancer. The low malignant degree of neuroendocrine cancer on the histology was called carcinoid, while the high degree was called small cell carcinoma. The small cell has no androgen receptor and doesn't express PSA. Pure

Am. J. Biomed. Sci. 2011, 3(1), 1-10; doi: 10.5099/aj110100001 small cell carcinoma at clinical stage was seldom seen, about $1 \%$ of prostate gland cancer. The small cell prostate carcinoma presented lamellar, nest form growth and often had neoplasm necrosis, with the chromosome being thin and uniform and the periplast being little. The nucleole was not obvious and often had caryocinesis. The small cell carcinoma expressed positively to the NE marking proteinum, such as CgA, Syn, NSE etc, and negative to the PSA or androgen receptor $[6,8]$. Three cases of prostate SCC secreting ADH have been reported [9, 10], Shigeo Kawai [10] first reported a case of small prostate carcinoma cells, coexpressed with PSA and ADH, and the SCC microscopically showed rosette formation and was positive for neuroendocrine markers.

Adopting the immunohistochemistry method, there was neuroendocrine differentiation of the gland cancer among $50 \%$ of the prostate cancer or so, and the poor prognosis of small cell carcinoma of prostate was similar to small cell carcinoma of the lung. About the $50 \%$ or so in the small cell carcinoma showed mixed prostate gland cancer composition. The patient's average existence period of the small cell prostate carcinoma was no longer than 1 year and there was no difference (c) 2011 by NWPII. All rights reserved. 
between the pure cellule carcinoma and mixture type small cellule carcinoma.

The clinical performance of the endocrine cancer of the prostate neuroendocrine carcinoma is similar to typical adeno cancer, but can appear as a special endocrine symptom in parts of cases, such as hydrocortisone, hypercalcemia or myasthenia gravis. We should pay attention to the discriminating diagnosis of poorly differentiated bladder cancer, lymphoid lump and original nerve epiblast tumor and so on.

The common prostate cancer appeared crystalloid inside the glandular cavity, with cell heteromorphism, cell nucleus aggrandizement, an obvious nucleole and single glandular epithelium. It was also short of base cell, familiar nerve encroachment, positive to the P504S marker, negative to p63 and anti-base cell of $34 \beta \mathrm{E} 12$ prostate antibody. The $\mathrm{p} 504 \mathrm{~S}$ expression rate of common prostate cancer was $82 \% \sim 100 \%$ and the calcyclin expression imperfection rate was similar to that of p63 in the prostate cancer for $95 \%$ or so [6].

Wenle Wang [8] reported 95 cases of small cell prostate carcinoma, the mean value of PSA level was $4.0 \mathrm{ng} / \mathrm{ml}$. 33 of the 78 patients exhibited the diagnosis history of common prostate cancer. The interval from the common gland cancer to small cell carcinoma was 1 300 months (average 25 months); percentage of pure small cell carcinoma was 54/95. In the mixture prostate cancer, if the composition of small cell reached above $80 \%$, the Gleason grade score of $85 \%$ patients was over 8 . Among them, $88 \%$ of the cases were positive to neuroendocrine marker, 14/73 patients were positive to PSA, while 17/61 patients were positive to (P501 S), 15/59 patients were positive to prostatic specific membrane antigen (PSM) and 23/44 were positive to thyroid gland transcription factor. The key of diagnosis as small cell carcinoma was an oaten form tumor cell alignment to rose form.

According to our results, the survival of small cell carcinoma was $1 \sim 30$ months (average 13 months), the average Gleason score was eight and the progression to small cell tumor indicated a poor prognosis and slight changes in the serum prostate-specific antigen level. This tumor might appear to respond to an androgen blockage

Am. J. Biomed. Sci. 2011, 3(1), 1-10; doi: 10.5099/aj110100001 therapeutic attempt. Early diagnosis and early treatment might improve the prognosis of the patients diagnosed as small cell prostate carcinoma.

The histogenesis of SCC of the prostate remains controversial. Some scholars preferred the hypothesis that SCC was derived from malignant transformation of normal prostate neuroendocrine cells [11]. However, it has been shown that neuroendocrine cells in the normal prostate epithelium represented postmitotic cells and no longer had proliferative activity. This made it unlikely that these cells would suddenly start to proliferate and become a highly aggressive SCC [12]. Others thought SCC represented a differentiated variant of the common adenocarcinoma. Schron DS reported that SCC was detected during the course of a previous adenocarcinoma [13]. The third hypothesis was that SCC derived from a multipotential stem cell of the prostatic epithelium [14-15].

Though scholars discovered prostate gland cancer cell neuroendocrine differentiation after the treatment of androgen blockage, mechanism was still not clear. Among them, the main signal path contained cAMP/PKA, Jak-STAT and PI3 K/AKT/mTOR signal path. The multipotent stem cells located on the base layer of prostate differentiated towards the neuroendocrine cell after androgen blockage and could carry on prostate gland canceration. Since the neuroendocrine tumor lacked the androgen receptor, it also didn't express Bcl2. Furthermore, it secreted the surviving proteinum to strengthen the ability of anti-apoptosis, and also produced the blood vessel endothelium growth factor (VEGF) so it could tolerate apoptosis caused by androgen blockade. More importantly, it could secrete peptide material (such as 5-HT and bombesin) and growth factor (such as vascular endothelial growth factor etc.), made by the surrounding cancer cell expressing Bcl2 and MIB1. This strengthens their ability of propagation and anti-apoptosis, and turned them to refractoriness of prostate cancer [16-19].

As regards to the treatment, the neuroendocrine carcinoma of the prostate gland was poor towards radiotherapy, not sensitive to endocrine treatment. At the earlier period of small 
cell carcinoma, we were able to perform the radical prostatectomy, but more patients had already belonged to a later period at final diagnosis, with most of them having no opportunity of radical prostatectomy. We advocated the chemotherapy combined with endocrine treatment to the prostate neuroendocrine carcinoma. If the tumor secreted catechol amine and calcitionin etc. to cause high blood pressure and other symptoms, the proper handle of the simultaneous phenomenon could raise the sufferer's living quality. To small cell prostate carcinoma, the chemotherapy could contract the sufferer's tumor. Katsuyuki Sano [17] reported a patient diagnosed as small cell prostate carcinoma with osseous metastasis, with tumor size of $5.9 \times$ $5.0 \times 4.6 \mathrm{~cm}$, through four periods of chemotherapy. The tumor contracted to $4.0 \times 4.0$ $\times 3.5 \mathrm{~cm}$ and the chemotherapy project was platinum $\left(60 \mathrm{mg} / \mathrm{m}^{2}\right.$, the $1^{\text {st }}$ day) and etoposide $\left(80 \mathrm{mg} / \mathrm{m}^{2}\right.$, the $1^{\text {st }}, 2^{\text {nd }}, 3^{\text {rd }}$ day), with granulocyte colony-stimulating factor (GCSF, $300 \mathrm{mg}$, connect to use 5 days). In three follow-up period chemotherapies, platinol and etoposide were reduced by $50 \%$ and $70 \%$, respectively, and 600 800 mg GCSF was continuously applied during treatment. At the beginning, the level of NSE was $35.9 \mathrm{ng} / \mathrm{ml}$, while lowered to $11.7 \mathrm{ng} / \mathrm{ml}$, and $7.4 \mathrm{ng} / \mathrm{ml}$, respectively, post 2 period and 4 period chemotherapies. The patient died in 3 months.

In great quantities, there are currently clinical studies with experiments having already confirmed a prostate gland cancer sufferer would appear NED inside the focus after endocrine treatment. In addition, the NED was an important factor which causes toleration to the endocrine therapy [16-21].

The research of future work should include particular emphasis on the research of the NED mechanism; especially the selectivity blockade of some signaling molecule to prevent or convert the NED of prostate cancer cell. There should also be work to identify how the materials the NE cell secretes through paracrine secretion or autocrine and which incentives exist in the growth of the nonandrogen dependent cell. Finally, there should be a design or creation of new chemotherapy medicine which aims at secretion of NE cell to improve the sufferer's living quality and survival rate of prostate cancer.

The multiple methods, such as hormone therapy in combination with the chemotherapy or transfer factor immunotherapy, can be used to raise the patient's survival rate. Bombesin / gastrin releasing peptide (BN / GRP) secreted by NE cell are the new therapeutic target [22,23].

We believe in the near future, the treatment which aims at NED mechanism will bring a new hope for the neuroendocrine carcinoma of the prostate sufferer. The cell based drug efflux assay can help to know the required chemotherapy to be given to the patents accurately and in much short time which significantly benefits cancer patients [24], we thought that whether we can use this method to select the suitable drug for chemotherapy of small cell prostate carcinoma is another promising study. From the clinical angle, we should advocate early diagnosis and early treatment of the prostate neuroendocrine carcinoma.

Joint first authors: TongLi Hao, YiGuang Wu, these authors contributed equally to this work.

\section{References}

1. Helpap, B.; Köllermann J; Oehler U. Neuroendocrine differentiation in prostatic carcinomas: histogenesis, biology, clinical relevance, and future therapeutical perspectives, Urol Int, 1999, 62(3), 133-138.

2. Oesterling, J.E.; Hauzeur, C.G.; Farrow GM. Small cell anaplastic carcinoma of the prostate: a clinical, pathological and immunohistological study of 27 patients, $J$ Urol, 1992, 147(3 Pt 2), 804-7.

3. di Sant'Agnese, P.A. Neuroendocrine differentiation in human prostatic carcinoma, Hum Pathol, 1992, 23(3), 287-96.

4. Miyoshi, Y.; Uemura, H.; Kitami, K.; Satomi, Y.; Kubota, Y.; Hosaka M. Neuroendocrine differentiated small cell carcinoma presenting as recurrent prostate cancer after androgen deprivation therapy, BJU Int, 2001, 88(9),9823. 
5. Tanaka, M.; Suzuki, Y.; Takaoka, K.; Suzuki, N.; Murakami, S.; Matsuzaki,O.; et al. Progression of prostate cancer to neuroendocrine cell tumor,Int J Urol, 2001, 8(8), 431-436.

6. Yao, J.L.; Madeb, R.; Bourne, P.; Lei, J.; Yang, $\underline{X}$.; Tickoo, S.; et al. Small cell carcinoma of the prostate: an immunohistochemical study, Am J Surg Pathol, 2006, 30(6),705-712.

7. Yuan, T.C.; Veeramani, S.; Lin, F.F.; Kondrikou, D.; Zelivianski, S.; Igawa, T.; et a1 . Androgen deprivation induces human prostate epithelial neuroendocrine differentiation of androgen sensitive $\mathrm{LNCaP}$ cells,Endocrine.related Cancer, 2006, 13(1), 151-167.

8. Wenle, Wang; Jonathan, I.; Epstein. Small Cell Carcinoma of the Prostate: A morphologic and immunohistochemical study of 95 Cases, Am J Surg Pathol, 2008, 32(1), 65-71.

9. Ghandur-Mnaymneh, L; Satterfield, S.; Block, N.L. Small cell carcinoma of the prostate gland with inappropriate antidiuretic hormone secretion: immunohistochemical and clinical expressions, J Urol, 1986, 135(6), 1263-6.

10. Shigeo, Kawai; Kenzo, Hiroshima; Yoshiaki, Tsukamoto; Toyofusa, Tobe; Hiroyoshi ,Suzuki; Haruo, Ito; et al. Small cell carcinoma of the prostate expressing prostate-specific antigen and showing syndrome of inappropriate secretion of antidiuretic hormone: An autopsy case report, Pathology International, 2003; 53(12), 892-896.

11. Patel, A.; Ball, A.J.; Chappell, M. Pure primary small cell carcinoma of the prostate, Br J Urol, 1993, 72 (3), 380-383.

12. Helpap, B.; Köllermann, J. Undifferentiated carcinoma of the prostate with small cell features: immunohistochemical subtyping and reflections on histogenesis, Virchows Arch, 1999, 434(5), 385-391.

13. Schron, D.S.; Gipson, T.; Mendelsohn, G. The histogenesis of small cell carcinoma of the prostate: an immunohistochemical study, Cancer, 1984, 53(11), 2478- 80.

14. Turbat-Herrera, E.A.; Herrera, G.A.; Gore, I.; Lott, R.L.; Grizzle, W.E.; Bonnin, J.M. Neuroendocrine differentiation in prostatic carcinomas: a retrospective autopsy study, Arch Pathol Lab Med, 1988, 112(11), 1100-5.

15. Weaver, M.G.; Abdul-Karim, F.W.; Srigley, J.R. Paneth cell-like change and small cell carcinoma of the prostate: two divergent forms of prostatic neuroendocrine differentiation, $\mathrm{Am}$ J Surg Pathol, 1992; 16(10), 1013-16.

16. Burchardt, T.; Burchardt, M.; Chen, M.W.; Cao, Y. de la Taille, A.; Shabsigh, A.;et a1.Transdifferentiation of prostate cancer cells to a neuroendocrine cell phenotype in vitro and in vivo, J Urol, 1999, 162(5),1800-1805.

17 Katsuyuki, Sano; Keikoku, Miyai; Sachiko, Yoshida. Small Cell Carcinoma of the Prostate: A Case Report, Int J Urol, 1997; 4(3), 321- 323.

18. Miyoshi, Y.; Uemura, H.; Kitami, K. Neuroendocrine differentiated small cell carcinoma presenting as recurrent prostate cancer after androgen deprivation therapy, BJU Int, 2001, 88 (9),982-983.

19. Tanaka, M.; Suzuki, Y.; Takaoka, K.; Suzuki, N.; Murakami, S.; Matsuzaki, O.; et al. Progression of prostate cancer to neuroendocrine cell tumor, Int J Urol, 2001, 8(8):,431-446.

20. Yashi, M.; Ishikawa, S.;Ochi, M.; Tokue, A. Small cell/neuroendocrine carcinoma may be a more common phenotype in advanced prostate cancer, Urol Int, 2002, 69(2), 166-168.

21 Burchardt, T.; Burchardt, M.; Chen, M.W.; Cao,Y.; de,la-Taille-A; Shabsigh,A.; et a1. Transdifferentiation of prostate cancer cells to a neuroendocrine cell phenotype in vitro and in vivo, $J$ Urol, 1999,162(5),1800-1805.

22. Stangelberger, A.; Schally, A.V.; Varga, J.L.; Hammann, B.D.; Groot, K.; Halmos, G.; et a1.Antagonists of growth hormone releasing hormone $(\mathrm{GHRH})$ and of bombes in gastrin releasing peptide (BN / GRP) suppress the expression of VEGF, bFGF, and receptors of the EGF / HER family in PC-3 and DU-145 human androgen-independent prostate cancers, The Prostate, 2005, 64(3), 303-315.

23. May, M.; Siegsmund, M.;Hammermann, F.; Loy, V.; Gunia S Prognostic significance of proliferation activity and neuroendocrine differentiation to predict treatment failure after 
radical prostatectomy, Urol Nephml, 2007, 41(5),375-381.

24. Arvinder Singh; Saranpal Singh. A Cell-based Drug Efflux Assay for Analysis of Multidrug
Resistance in Cancer Patients, Am J Biomed Sci, 2010, 2(2), 178-183. 